\title{
Un alma enferma. La experiencia religiosa de Wittgenstein a la luz de Las variedades de la experiencia religiosa de William James*
}

\author{
VICENTE SANFÉLIX VIDARTE \\ Departamento de Metafísica y Teoría del Conocimiento \\ Universidad de Valencia \\ Vicente.Sanfelix@uv.es
}

Resumen: Este artículo defiende que Wittgenstein puede ser considerado como un alma enferma a la luz de Las variedades de la experiencia religiosa de William James. Asimismo, se muestra que de la lectura de este libro Wittgenstein extrajo un ideal religioso que explica varios aspectos de su biografía, su hostilidad a la civilización burguesa y el sentido religioso de su filosofía.

Palabras clave: religión, melancolía, civilización, filosofía

\begin{abstract}
This article maintains that Wittgenstein can be seen as a sick soul in the terms of William James' The Varieties of the Religious Experience. It also holds that from the reading of this book Wittgenstein adopted a religious ideal that explains some aspects of his biography, his hostility to bourgeois civilization and the religious meaning of his philosophy.
\end{abstract}

Key words: religion, melancholy, civilization, philosophy

\section{Un psicólogo superficial y un buen filósofo}

Las relaciones de Wittgenstein con el pensamiento de James muy probablemente no han recibido todavía toda la atención que merecen. Se dirá que, al fin y al cabo, el filósofo norteamericano apenas aparece aludido en los escritos del pensador austriaco que han llegado hasta nosotros, y que en las escasas y raras ocasiones en las que Wittgenstein admite la influencia en él de otros pensadores, el nombre de aquél brilla por su ausencia. Y aunque es cierto que el Wittgenstein maduro se sirvió de Los principios de psicología en sus clases, no lo es menos que los utilizaba con afán polémico, como una manera de ilustrar los errores conceptuales en la comprensión de lo psíquico que una buena terapia filosófica había de corregir. Es decir, y diciéndolo con la ayuda de la

*El presente trabajo se ha beneficiado de la ayuda concedida por el Ministerio de educación y ciencia para llevar adelante el proyecto de investigación: "Cultura y civilización: el contexto intelectual de la constitución de la filosofía del primer Wittgenstein" (HUM2005-04665). Por otra parte, deseo agradecer a Ángel Faerna, Gerardo López Sastre, Carmen Ors, Witold Jakorzynski y Óscar Nudler los comentarios que me hicieron a versiones anteriores de este artículo. Igualmente, a los dos árbitros anónimos de Diánoia, pues sus observaciones me han sido de gran ayuda.

Diánoia, volumen LII, número 59 (noviembre 2007): pp. 67-96. 
propia expresión de Wittgenstein en Tractatus 5.5421, James era a sus ojos no más que un eximio representante de la "psicología superficial" de su tiempo.

Sin embargo, no puede decirse lo mismo de otro libro de James que Wittgenstein leyó en su juventud, Las variedades de la experiencia religiosa, pues es el caso que disponemos de buenos testimonios de la altísima estima en que lo tenía. Así, por ejemplo, esta conversación sostenida entre Drury y Wittgenstein allá por 1930:

DRURY: Encuentro a Lotze muy difícil de comprender, muy aburrido.

WITTGENSTEIN: Se trata de un hombre al que no se le debió haber permitido escribir filosofía. Pero un libro que usted debe leer es el de William James Varieties of Religious Experience; ése es un libro que a mí me ayudó mucho en una época.

DRURY: Oh, sí, lo he leído. Siempre he disfrutado la lectura de cualquier cosa de James. Es una persona muy humana.

WiTTGENSTEIN: Eso es lo que lo convierte en un buen filósofo. Era un auténtico ser humano. ${ }^{1}$

De modo que, según atestigua este testimonio, aunque James hubiera sido, a los ojos de Wittgenstein, un psicólogo superficial, ello no le impedía ser un buen filósofo.

En lo que sigue nos olvidaremos de los Principios de la psicología y nos concentraremos en la relación de Wittgenstein con Las variedades de la experiencia religiosa.

\section{El alivio de la Sorge}

Prima facie no resulta fácil entender, dado el antipsicologismo de Wittgenstein, ${ }^{2}$ su aprecio por esta obra de James. Al fin y al cabo, éste

${ }^{1}$ M. O'C. Drury, "Conversaciones con Wittgenstein", pp. 181-182.

${ }^{2}$ Antipsicologismo que tiene diversas concreciones. En el primer Wittgenstein, el antipsicologismo tenía el mismo sentido que en Frege o Russell; esto es, un repudio del intento de reducir las leyes lógicas a leyes psicológicas. Pero no sólo tenía este sentido, el antipsicologismo del primer Wittgenstein es también una condena de la arquitectónica que pone en su base una teoría del conocimiento contaminada de "inesenciales investigaciones psicológicas"; cfr. los Preliminares de las "Notas sobre lógica" y la observación del 10 de noviembre de 1914 del Diario filosófico (19141916). A esto habría que añadir que Wittgenstein siempre mantuvo una posición escéptica respecto de los derroteros de una psicología que pugnaba por constituirse en una ciencia natural más.

Diánoia, vol. LII, no. 59 (noviembre 2007). 
empieza el ciclo de conferencias que constituyen su libro advirtiendo que, dada su incompetencia en esos campos, no abordará la cuestión de la religión desde la perspectiva del teólogo, ni desde la del erudito, ni desde la del historiador de las religiones, ni siquiera desde la del antropólogo, sino desde la del psicólogo, ya que, como confiesa, "la psicología es la única rama del saber en la que estoy especializado". ${ }^{3}$ Y aunque ciertamente hacia el final del libro James aborda la cuestión desde una perspectiva filosófica, sospecho que justamente ésa podría ser la parte de la obra - sobre todo la que se contiene en forma de postscriptum, pero también el final de la conferencia XVIII- con la que Wittgenstein podría haber tenido más reparos.

Si Las variedades de la experiencia religiosa es, fundamentalmente, un libro de psicología y Wittgenstein era un antipsicologista, ¿qué le pudo atraer tanto de ese libro? Creo que, precisamente, la psicología en él contenida.

Si algo llama la atención en este libro es la gran cantidad de testimonios que contiene. La profusa utilización de "documents humains", ${ }^{4}$ como el mismo James los califica, para ilustrar y respaldar sus tesis. Muy probablemente este detalle podría darnos una pista del tipo de literatura psicológica que Wittgenstein se hubiera mostrado más propenso a aceptar: una psicología empírica, descriptiva, profunda, como la que suele ser habitual en muchos planteamientos clínicos, antes que una de amplias aspiraciones generalizadoras y teóricas, explicativa, experimental... Pero sea lo que fuere de esta hipótesis, no pretendo ahora detenerme en ella. Más bien, lo que quiero sugerir es otra que me parece mucho más fácilmente justificable; a saber: que lo que Wittgenstein encontró en el libro de James, en la lectura de todos aquellos testimonios, fue un gran alivio psicológico; un alivio que se lo pudo proporcionar el reconocimiento de su caso en los casos de otros. ${ }^{5}$

En ese sentido creo que apunta la observación, que ya hemos citado, que Wittgenstein le hizo a Drury, a quien, recuérdese, le confesaba que esta obra le había proporcionado mucha ayuda en cierta época. Y en el mismo sentido, sólo que más explícitamente, apunta la carta que le escribió a Russell el 22 de junio de 1912, en la que puede leerse:

${ }^{3}$ Cfr. W. James, Las variedades de la experiencia religiosa, conferencia I, p. 25.

${ }^{4}$ Ibid., p. 25.

${ }^{5}$ Coincidimos en este punto con B. McGuinness cuando señala: "Podía reconocer su propia condición en el capítulo de William James sobre 'El alma enferma'", Wittgenstein. El joven Ludwig (1889-1921), p. 214. No obstante, McGuinness añade justo a continuación algo con lo que no estamos de acuerdo: "Sin embargo, lo que aquí estamos describiendo no es ninguna enfermedad." 
Cuando tengo tiempo, leo ahora las variedades de la exp[eriencia] religiosa de James. Este libro me hace muchísimo bien. No quiero decir que pronto seré un santo, pero no estoy seguro de que no me mejore un poco en un aspecto en el que quisiera mejorar mucho: a saber, creo que me ayuda a liberarme de la Sorge (en el sentido en que usó Goethe la palabra en la segunda parte de Fausto). ${ }^{6}$

En efecto, en el acto V de la II parte del Fausto, con la muerte ya en el horizonte, comparecen sus cuatro encanecidas hermanas Escasez, Culpa, Necesidad e Inquietud (Sorge). De las cuatro, sólo esta última consigue colarse en la morada del rico Fausto, quien, según propia confesión, hasta ese momento sólo se ha dedicado a correr por el mundo "agarrando el placer por los cabellos", dejando "estar lo que no me satisfizo", no haciendo otra cosa "más que anhelar y realizar, y otra vez desear", y teniendo por loco a "quien mira allá, parpadeante, e inventa algo como él sobre las nubes", desprecia la eternidad y se limita a seguir "el día terrenal". Pues bien, he aquí el discurso que Sorge le dirige:

A quien poseo yo por una vez

no le sirve de nada el mundo entero;

a cubrirle desciende eterna sombra, pero el sol no se pone ante sus ojos, en su mente, perfecta exteriormente habitan las tinieblas interiores, y no sabe tomar la propiedad

${ }^{6}$ L. Wittgenstein, Cartas a Russell, Keynes y Moore, p. 16. Russell atribuiría después a la lectura del libro de James el servir de detonante al misticismo de Wittgenstein que tanto le sorprendió cuando se encontró con él en La Haya, en diciembre de 1919, para discutir el Tractatus. Al respecto, el 20 de aquel mismo mes escribía a Lady Ottoline:

En su libro había percibido cierto aroma de misticismo, pero me quedé asombrado cuando descubrí que se había convertido en un místico completo. Lee a autores como Kierkegaard y Ángelus Silesius, y considera seriamente la posibilidad de hacerse monje. Todo empezó con Las variedades de la experiencia religiosa, de William James, y fue en aumento (lo que no es de extrañar) durante el invierno que pasó solo en Noruega antes de la guerra, cuando estuvo a punto de volverse loco" (ibid., pp. 75-76).

Indudablemente, el pensamiento y la experiencia religiosa de Wittgenstein sufrió la influencia poderosa de otros autores, como Kierkegaard, Silesius o Tolstoi, a quien Russell no alude en esta ocasión. Pero de creer este testimonio del filósofo británico - y no conozco razones poderosas para ponerlo en duda-, la de James habría sido la influencia más original sobre este aspecto de su pensamiento y personalidad.

Diánoia, vol. LII, no. 59 (noviembre 2007). 
de todos los tesoros de la tierra.

La dicha y la desdicha le enloquecen;

se muere de hambre en medio del exceso,

y lo mismo delicia que tormento,

para el día siguiente va aplazándolo;

sólo tiene presente el porvenir

y así jamás consigue terminar. ${ }^{7}$

Es comprensible que el joven y rico Wittgenstein, dedicado él también a "agarrar el placer por los cabellos", reiteradamente tentado por la idea del suicidio, obsesionado por la inminencia de la muerte y asaltado por la idea de que su vida podría carecer de valor -al fin y al cabo, a la altura de 1912 Wittgenstein sólo era un ingeniero frustrado y una especie de filósofo amateur- pudiera identificarse con el héroe de Goethe y sentirse, como Fausto, interpelado por una Sorge $e^{8}$ que el libro de James le ayudaba a aliviar proponiéndole un ideal que, aunque inalcanzable, le permitía mejorar: la santidad.

\section{La melancolía religiosa}

En su escrito, James contrapone dos grandes tipos de personalidad religiosa: la que él denomina la mentalidad sana, por un lado, a la que dedica las conferencias IV y V, y el alma enferma por el otro, a cuya presentación dedica las dos conferencias siguientes; esto es, las VI y VII. De la primera poco vamos a decir aquí, baste con la propia caracterización que de ella da el mismo James: "denominamos mentalidad sana a la tendencia que contempla todas las cosas y las encuentra buenas". 9 Evidentemente, no era la mentalidad de Wittgenstein quien, como acabamos de ver, se reconocía afectado de Sorge, ni tampoco la de James, quien, a pesar del principio de asepsia científica que intenta respetar en su descripción de las diversas modalidades de personalidades religiosas, no duda en otorgar primacía a la mentalidad mórbida por su mayor

${ }^{7}$ J.W. Goethe, Fausto, pp. 334 y ss.

${ }^{8}$ Los diarios de David Pinsent pueden ilustrar todos y cada uno de los puntos a los que aquí aludimos: la vida de rico un tanto estrafalario y caprichoso que el joven Wittgenstein llevaba, sus tentaciones suicidas, su obsesión con la posibilidad de una muerte inminente y de que su trabajo en filosofía pudiera quedar incompleto o carecer de valor... Cfr. G.H. Von Wright, Retrato del joven Wittgenstein. Por cierto, en contra de lo que vimos opinaba McGuinness, Pinsent no dudaba de la naturaleza neurótica y enfermiza de Wittgenstein por aquellas fechas.

${ }^{9}$ Las variedades de la experiencia religiosa, p. 133. 
capacidad para hacerse cargo de una faceta innegable de la realidad que la mentalidad sana simplemente elide: el mal. ${ }^{10}$

Si analizamos la caracterización que da James de la personalidad morbosa, lo primero que hay que constatar es que para él estas mentalidades no se limitan a considerar el mal como un simple desajuste, subsanable, con las cosas, a la manera en que el catolicismo y las razas latinas y más viriles propenden, según él, a concebirlo, sino que, más en línea con el protestantismo y las mentalidades más femeninas y germánicas, tiende a ver el mal como algo más radical y general. ${ }^{11}$ Para llegar a ser un alma enferma, es preciso tener bien presentes el inevitable fracaso vital, ${ }^{12}$ la fugacidad de los bienes, ${ }^{13}$ la posibilidad de la enfer-

${ }^{10}$ Véase ibid., p. 229-230:

Fieles a nuestra actitud de observadores imparciales, ¿qué debemos decir de esta lucha? [...] la mentalidad morbosa abraza una escala de experiencia más amplia [...]; la mentalidad sana [...] es inadecuada como doctrina filosófica porque los hechos malignos que rechaza positivamente considerar constituyen una porción genuina de la realidad.

No obstante, las razones de James para favorecer la mentalidad mórbida no eran simplemente ontológicas - la realidad efectiva del mal en el mundo-, sino también subjetivas: él mismo era una de esas almas enfermas cuyo testimonio presenta (de hecho parece que es su propia experiencia la que se esconde detrás del caso del paciente cuyo informe dice traducir del francés; cfr. ibid., pp. 225-227). Llevaría, pues, razón Taylor cuando en su breve pero agudo análisis del libro de James afirma que el análisis que éste proporciona de la religión "era una parte importante de su apologia pro fide sua". Ch. Taylor, Las variedades de la religión hoy, p. 52.

${ }^{11}$ Cfr. Las variedades de la experiencia religiosa, pp. 125, 194 y 204 nota 9.

${ }^{12}$ Véase ibid., p. 197:

Pero cojamos al hombre más feliz, el más envidiado del mundo, y nueve de cada diez veces su más íntima conciencia es de fracaso. $\mathrm{O}$ bien sus ideales sobre el éxito son mucho más elevados que los resultados obtenidos, o bien acaricia ideales secretos que el mundo no conoce, de los cuales sabe interiormente que carece.

De la conciencia de lo inevitable del fracaso da James los testimonios de Goethe, Lutero y Stevenson.

${ }^{13}$ Véase ibid., p. 200:

Todos los bienes naturales perecen. La riqueza tiene alas, la fama es suspiro, el amor una estafa, la juventud, la salud y el placer desaparecen. Las cosas que siempre acaban siendo polvo y desencanto, ¿pueden constituir los bienes auténticos que añoran nuestras almas? Al final de todo aletea el gran espectro de la muerte universal...

Diánoia, vol. LII, no. 59 (noviembre 2007). 
medad y la seguridad de la muerte. ${ }^{14} \mathrm{Y}$ ni siquiera bastará con esto. El pesimismo ha de ser más extremo; no tanto el resultado de una observación del mundo o de una reflexión sobre la muerte cuanto, apunta James, una auténtica entrega a la melancolía patológica. ${ }^{15}$ Esta melancolía no será sólo pasiva —incapacidad para el goce, anhedonía-, sino que habrá de ser activa —una especie de neuralgia psíquica-. Y, sin embargo, a pesar de su severidad patológica, no deberá degradarse en simple desesperación quejumbrosa si es que no ha de abocarse a la irreligiosidad; pues, para ser religiosa, esta melancolía, a pesar de su rigor, ha de dejar lugar a la esperanza de un renacimiento. ${ }^{16}$ James expone tres ejemplos de "melancolía religiosa"; pero antes de aludir a ellos, hace una consideración.

Hemos dicho que para el filósofo norteamericano la experiencia religiosa más perfecta es la de la mentalidad morbosa, la de los nacidos dos veces, no la de los nacidos de una sola vez con una mente sana. $\mathrm{Y}$ ahora vemos que la enfermedad del alma de aquellos no la entiende como una metáfora ni como un pleonasmo, sino, literalmente, como un auténtico desequilibrio patológico. ¿No es esta posición, a la postre, de una gran irreverencia? ¿No estaría cerca James, después de todo, de, por ejemplo, Nietzsche (o incluso de Hume, quien también reconocía en los inexplicables temores que respecto al futuro sufren algunas mentes - la Sorge - una de las fuentes de la creencia religiosa)? ${ }^{17}$

Una conclusión semejante sería errónea, pues lo que hay que tener en cuenta es que, para el autor de Las variedades, la genialidad más auténtica es la que resulta de la combinación de un carácter psicopático con unas facultades intelectuales muy elevadas. ${ }^{18}$ De hecho, sería este

14 "El hecho de que podemos morir, podemos enfermar, nos desconcierta; el hecho de que ahora, por un momento, vivimos y estamos a gusto, es irrelevante para ese desconcierto" (ibid., p. 201).

${ }^{15}$ Cfr. ibid., p. 207.

${ }^{16}$ Cfr. ibid., pp. 211 y 213.

${ }^{17}$ James tiene bien presente a Nietzsche, con cuyas tesis sobre la santidad confronta las suyas propias en las conferencias XIV y XV. Cfr. ibid., p. 497. Por lo que respecta a Hume, son varios los lugares de su obra en los que se relacionan la creencia religiosa y el terror ante el futuro. Cfr. por ejemplo, su ensayo "Sobre la superstición y el entusiasmo". Para una comparación de la filosofía de la religión de James con la de Hume, cfr. el brillante ensayo de G. López Sastre, "Un diálogo imaginario sobre el mundo religioso. William James y David Hume se encuentran".

18 "Así, cuando un psicópata y un intelectual elevado convergen [. . .] en el mismo individuo, conseguimos la mejor condición posible para el tipo de genio efectivo según llega a los repertorios biográficos" (ibid., p. 51). 
temperamento psicopático, con su tendencia a la emotividad extrema y a la obsesión y las ideas fijas, el que daría al genio la obstinación que le permite perseguir sin descanso sus ideas nuevas y no quedar tranquilo hasta que consigue desahogarse haciéndolas públicas. ${ }^{19}$ De modo que para James bien podríamos decir que la melancolía patológica era una condición prácticamente sine qua non de la genialidad, la religiosa incluida.

Hecho este inciso podemos volver a la caracterización jamesiana de la melancolía religiosa. Como adelantábamos, nuestro autor expone, sin afán de exhaustividad, tres ejemplos de ella. El primero de ellos, que ilustra con el caso de Tolstoi, se caracteriza por lo que podríamos llamar una pérdida de sentido del mundo en su conjunto. Vale la pena citar al mismo James:

Imaginaos, si podéis, privados súbitamente de todas las emociones que ahora os inspira el mundo, e intentad imaginarlo tal como es, puramente, solo, sin vuestro comentario favorable o desfavorable, esperanzado o aprensivo. Casi os será imposible percibir tal situación de negatividad y muerte, ninguna parcela del universo tendría entonces mayor importancia que otra... el mundo real, práctico para cada uno de nosotros, el mundo efectivo del individuo, es el mundo compuesto, donde los hechos físicos y los valores emocionales están combinados de manera indiscernible; retirad o alterad cualquier factor de este complejo y obtendréis el tipo de experiencia llamada patológica.

En el caso de Tolstoi, la sensación de que la vida poseía algún significado desapareció por completo... y el resultado fue una transformación en la expresión total de la realidad. ${ }^{20}$

Si la melancolía de Tolstoi se manifiesta como la pérdida de sentido del mundo, el segundo caso de melancolía religiosa, que James ilustra con la figura de John Bunyan, ${ }^{21}$ gira en torno a la sensación de pecado y culpabilidad:

Mientras que las preocupaciones de Tolstoi -leemos - eran bastante objetivas, ya que aquello que le interesó fue el propósito y el significado

${ }^{19} \mathrm{Cfr}$. ibid., p. 50. El tema de la relación entre genialidad y psicopatía es prácticamente tan antiguo como la filosofía misma. Baste recordar aquí el pequeño tratado aristotélico sobre la relación entre melancolía y genialidad en el que el Estagirita ponía como ejemplo de tal relación los casos tanto de Sócrates como de Platón.

${ }^{20}$ Ibid., pp. 214-215.

${ }^{21}$ John Bunyan (1628-1688) fue un predicador inglés atormentado por la idea de pecado. Fue autor, entre otras obras, de The Pilgrim's Progress.

Diánoia, vol. LII, no. 59 (noviembre 2007). 
general de la vida, los problemas de Bunyan trataron siempre de su situación personal. Constituyó un típico caso de temperamento psicopático, con una sensibilidad de conciencia hasta unos niveles patológicos; perseguido por dudas, miedos e ideas fijas, víctima de automatismos verbales tanto motores como sensoriales... A todo esto había que añadir una temerosa melancolía, auto-menosprecio y desesperación. ${ }^{22}$

Con ser terribles los sufrimientos melancólicos de Tolstoi o Bunyan, la experiencia de la pérdida de sentido del mundo o el sentimiento de culpabilidad, el peor tipo de melancolía es, para el autor de Las variedades, el tercero que presenta, el de un anónimo paciente que escribe en francés y tras el cual muchos son los que han visto al mismo James; paciente cuya melancolía se manifiesta en forma de un pánico universal; es decir: de pánico a volverse loco.

Cuando me encontraba en ese estado de pesimismo filosófico y depresión general de ánimo, un atardecer entré en el vestidor en penumbra para coger algo. De repente, sin previo aviso, cayó sobre mí, como si surgiese de la oscuridad, un miedo horrible. Simultáneamente apareció en mi mente la imagen de un paciente epiléptico que había visto en el manicomio... Esta imagen y mi miedo entraron en una especie de complicidad mutua. Yo soy así potencialmente. Nada de cuanto poseo me puede preservar de este hado, si llegase mi hora como llegó para él. Sentí tal horror de ser como él y tan cercano a su estado que fue como si algo, hasta ahora sólido dentro de mi pecho, se hubiese roto y convertido en una masa temblorosa de miedo. Después de todo esto cambió por completo el universo, me despertaba cada mañana con un terrible temor en la boca del estómago, y con una sensación de inseguridad que nunca había sentido y que jamás he vuelto a sentir... el miedo era tan envolvente y poderoso que si no me hubiera aferrado a textos de la Escritura como "El Dios eterno es mi refugio", "Venid a mí cuantos trabajáis y soportáis cargas pesadas", o "Yo soy la vida y la resurrección", creo que me habría vuelto loco. ${ }^{23}$

En resumidas cuentas, para James, en la genialidad se dan la mano inteligencia y psicopatía, y las experiencias religiosas más geniales, las más valiosas, exigen una mentalidad mórbida, anhedonista, un pesimismo general y exacerbado, patológico; en suma: una melancolía que puede ejemplificarse en la sensación de pérdida de sentido del mundo, de autodesprecio, o de terror a volverse loco.

${ }^{22}$ Ibid., p. 222-223

${ }^{23}$ Ibid., pp. 226-228.

Diánoia, vol. LII, no. 59 (noviembre 2007). 


\section{Las penas del joven Wittgenstein}

¿Pudo el joven Wittgenstein reconocerse en este retrato? Desde luego reunía muchas condiciones para tener un yo dividido como, según asevera James, es propio de las mentalidades psicopáticas. Hijo de severo padre protestante y de amable madre católica; judío que, no obstante, se consideraba como miembro de la raza germánica, ${ }^{24}$ alemán pero dentro de un imperio, el austriaco, sometido a las tensiones centrífugas de los nacionalismos; estudiante de ingeniería reconvertido a estudiante de filosofía, con un futuro profesional incierto, ${ }^{25} \mathrm{y}$ todo ello por no decir nada de su atormentada sexualidad... Que Wittgenstein no se hubiera sentido conmovido por el libro de James, que no se hubiera reconocido en muchos de los documents humains que tan prolijamente allí se proporcionaban hubiera sido casi milagroso. De hecho, creo que hay evidencias más que sobradas de que Wittgenstein exhibió todos y cada uno de los síntomas de la melancolía que James describe en el capítulo que en su libro dedica al alma enferma.

Para empezar, lo que viene a mostrar una lectura de los diarios y documentos personales de Wittgenstein que nos han llegado son las dudas, aquellas dudas de las que James ponía a Goethe como ejemplo, tanto acerca de su capacidad para culminar su trabajo cuanto, lo que resulta mucho más importante, del valor del mismo. ${ }^{26}$

${ }^{24}$ Como muchos de sus contemporáneos, Wittgenstein parece haber tenido una propensión al determinismo racial — ya lo vimos en James-:

¡Por ello siento hoy más que nunca la horrible tristeza de nuestra situación - la de la raza alemana - iPues me parece seguro que no podemos superar a Inglaterra! iLos ingleses — la mejor raza del mundo- no pueden perder! iPero nosotros sí podemos perder, y perderemos, si no este año, el próximo! Me deprime terriblemente la idea de que vaya a ser derrotada nuestra raza, ipues yo soy alemán de los pies a la cabeza! (anotación del 25 de octubre de 1914, Diarios secretos)

${ }^{25}$ Aunque Wittgenstein había obtenido la categoría de advanced student en la universidad de Cambridge en 1912, iba a fracasar en su pretensión de obtener el título de Bachelor of Arts. Todas estas peripecias se pueden encontrar, resumidas, en la introducción de W. Baum a su edición de los Diarios secretos, y más ampliamente tratadas en su libro Ludwig Wittgenstein. Vida y obra. No obstante, Baum no considera que por la época en que Wittgenstein leyó el libro de James su futuro profesional fuera algo que le preocupara. Aun si fuera así, lo que de seguro preocupaba a Wittgenstein era la posible futilidad de su trabajo.

${ }^{26}$ Un ejemplo entre innumerables: "Mi libro, el Tratado log. fil., al lado de cosas buenas y auténticas contiene también kitsch, es decir, fragmentos con los que he

Diánoia, vol. LII, no. 59 (noviembre 2007). 
Para continuar, es obvio que más de una vez Wittgenstein adoptó aquella estrategia estoica de insensibilización ante los bienes del mundo que James presenta como el paso más consumado que la cultura griega consiguió dar en la dirección del pesimismo. ${ }^{27}$

Pero lo más decisivo es que en Wittgenstein se pueden encontrar síntomas de los tres ejemplos de melancolía que pone James. Por empezar por la última, la que aquejó al propio filósofo norteamericano, el terror a la locura era una experiencia que Wittgenstein conocía bien. ${ }^{28}$ De igual manera, como Bunyan, Wittgenstein vivió muchas veces la angustia del pecado ${ }^{29}$ y, por último, como su admirado Tolstoi, sintió el mundo como huérfano de todo valor.

rellenado vacíos y en mi propio estilo, por así decirlo. No sé qué porción del libro representan tales fragmentos y es difícil juzgarlo ahora correctamente" (Movimientos del pensar. Diarios 1930-32/1936-37, p. 35). Por lo demás, merece notarse que Wittgenstein hace una censura estética de su libro. He tratado el tema de las dudas que Wittgenstein tenía acerca del valor de su trabajo filosófico, así como de su consideración estética del mismo, en "Una filosofía del espíritu. Wittgenstein y la cuestión judía".

${ }^{27}$ Véase Las variedades de la experiencia religiosa, pp. 205-206:

La insensibilidad estoica y la resignación epicúrea constituyeron los más grandes avances que consiguió el pensamiento griego en esa dirección. El epicúreo decía: "Evitad el desencanto esperando poco..." El estoico decía: "El único bien genuino que la vida puede proporcionar a un hombre consiste en la libre posesión de su alma, los demás bienes son mentira." Cada una de estas filosofías es, en su propio nivel, una filosofía de desengaño de los favores de la naturaleza... seguramente las actitudes estoica y epicúrea serán siempre típicas y marcarán cierto estadio concreto, alcanzado en la evolución del alma dentro de un mundo enfermo. Señalan el final de lo que llaman época de los nacidos una vez y representan los más altos vuelos de lo que la religión renacida llamaría el hombre puramente natural.

Que Wittgenstein opta por la estrategia estoica —antes que por la epicúrea- es obvio en su Diario secreto, en el que, por ejemplo, puede leerse: "No dependas del mundo exterior y así no necesitarás temer lo que en él ocurra... Es más fácil ser independiente de las cosas que de las personas. iPero también hay que poder lograr esto!" (anotación del 4 de noviembre de 1914).

28 "Con frecuencia tengo miedo de la locura", se lee en Aforismos. Cultura y valor, aforismo 303. Sobre la locura y Wittgenstein puede consultarse el trabajo de J.M. Ariso, "Ich bin wahnsinnig geworden. Me he vuelto loco". Por otra parte, sabemos por Drury que Wittgenstein había padecido de temores patológicos desde su misma niñez.

29 “[M]i vida está LLENA de los más feos y mezquinos pensamientos imaginables... Mi vida ha sido hasta ahora una gran porquería, pero: ¿es necesario que esto continúe indefinidamente?" (carta a B. Russell del 3 de marzo de 1914, Cartas a Russell, Keynes y Moore, p. 54). 
A este respecto, con su habitual estilo iconoclasta, Ernest Gellner denunció el carácter depresivo de la ontología del Tractatus, una ontología, recuérdese, en la que el mundo carece de todo sentido intrínseco y todos los hechos que lo componen tienen exactamente el mismo valor, esto es: ninguno; ${ }^{30}$ de ahí que, con su típico sarcasmo, el pensador checo llegara a hablar de aquella obra como un intento de justificar las penas del joven Werther merced a la notación lógica de Russell y Whitehead. ${ }^{31}$ La comparación es extremadamente pertinente, dado el aprecio que Wittgenstein tenía por Goethe ${ }^{32}$ sólo que Gellner podría haber ido más lejos: Werther era Wittgenstein. $\mathrm{O}$ aún peor: Wittgenstein era James, y Bunyan, y Tolstoi, y Epicteto, y Goethe en sus momentos depresivos... todos en uno.

\section{5. $Y$ todo es vanidad}

De modo que Wittgenstein es más que probable que hubiera de sentirse reconocido en el retrato que James daba en su libro del alma enferma. A buen seguro, su testimonio no habría desentonado con los de aquellos ilustres melancólicos que la obra recogía. Después de todo, el asunto podía tener una parte buena. ¿Acaso no era la melancolía, según vimos, una condición de la genialidad?

Pero repárese en que encontrar consuelo en semejante reflexión significaría que no se estaba privado de todo atisbo de una mentalidad sana, que aunque fuera en una mínima medida se participaría de esa actitud que en todo encuentra algo bueno. Desde luego no era el caso de Wittgenstein. Sus dudas acerca del valor de su propio trabajo son igualmente dudas, casi obsesivas, acerca de su propia genialidad. ${ }^{33}$

30 "El sentido del mundo tiene que residir fuera de él. En el mundo todo es como es y todo sucede como sucede; en él no hay valor alguno, y si lo hubiera carecería de valor" (Tractatus Logico-Philosophicus, 6.41 (1)).

${ }^{31}$ Cfr. E. Gellner, Lenguaje y soledad, capítulos 11-13.

${ }^{32}$ Ya hemos visto un punto en el que Goethe proporcionó, con su retrato de un Fausto aquejado de Sorge, un motivo de identificación al joven Wittgenstein. Pero la influencia de Goethe sobre el pensamiento de Wittgenstein es mucho más profunda. J. Bouveresse la ha tratado en su ensayo: "Antropología y cultura: sobre una posible deuda de Wittgenstein con Goethe y Spengler" en Wittgenstein. La modernidad, el progreso y la decadencia.

33 “El 'genio' judío es sólo un santo. El mayor pensador judío es sólo un talento. (Yo, por ejemplo.)"

"Creo que hay una verdad si pienso que, de hecho, mi pensamiento es sólo reproductivo. Creo que nunca he descubierto un movimiento intelectual, siempre me fue dado por algún otro..." (Aforismos. Cultura y valor, aforismo 101.) El texto

Diánoia, vol. LII, no. 59 (noviembre 2007). 
Ahora bien, la situación es incluso peor que todo esto. Pues para llegar a hacerse un problema de la propia genialidad uno debe, al menos, sospechar que podría pensarse bajo algún respecto que se está cerca de ella. Pero si sincera e íntimamente se duda de que ese sea el caso — si uno tiene íntima conciencia de que, al margen de lo que externamente pueda parecer, uno es un fracasado-, entonces incluso los momentos de duda acerca de la propia genialidad - no digamos ya el consentir que otros lo crean- han de convertirse en otros tantos casos de fatua vanidad. ${ }^{34}$

Creo que estamos ahora muy cerca del centro de la melancolía wittgensteiniana: la vanidad. ${ }^{35}$ Un pecado a la vez intelectual —nuestra falta es que no llegamos adonde quisiéramos o debiéramos- y moral - pero nos deleitamos engañándonos, y a veces incluso engañando a otros, al respecto-. Un centro del que la lectura de James, con sus tesis acerca de la correlación entre genialidad y psicopatía, pudo haberle hecho más consciente precisamente en la misma medida en que la fortalecía.

Lo que quiero decir es que sospecho que Wittgenstein estaba inmerso en una melancolía que no era para nada estática, sino dinámica; una melancolía abismal que se retroalimentaba y tenía forma de bucle, de espiral. Como la propia vanidad que constituía su centro neurálgico, de la que incluso la determinación de ponerle coto terminaba por volverse ella misma sospechosa de ser vanidosa. ${ }^{36}$

es revelador de cómo su estatus de judío pudo influir en sus dudas respecto de su propia genialidad, tema que ya traté hacia el final del ya mencionado trabajo "Una filosofía del espíritu. Wittgenstein y la cuestión judía". Por otra parte, es igualmente revelador de cómo, dentro de las problemáticas expectativas de Wittgenstein, no estaba sólo la genialidad, sino igualmente la santidad. Recuérdese, a este respecto, la carta igualmente ya aludida que dirigió a Russell en 1912 y en la que le hablaba del bien que le hacía leer Las variedades de la experiencia religiosa de James, aunque no pensaba que fuera a convertirlo de manera inmediata en un santo.

34 "Autoconocimiento y humildad es lo mismo" (Movimientos del pensar, p. 66).

35 "Ensucio todo con mi vanidad", confiesa Wittgenstein en ibid., p. 61.

${ }^{36}$ Véase ibid., p. 81 :

Cuando digo que quiero deshacerme de la vanidad es cuestionable si no lo quiero sólo por vanidad también. Soy vanidoso y en tanto que soy vanidoso mis deseos de mejora son vanidosos también. Entonces me gustaría ser como éste y aquél que no era vanidoso y que me agrada y calculo ya en espíritu el provecho que sacaría de "deshacerme" de la vanidad. Mientras se está sobre el escenario se es actor, hágase lo que se haga. 


\section{A los ojos de Dios}

Que Wittgenstein llegaría a hacer de esta melancolía una interpretación religiosa - como, por otra parte, el mismo James de la suya, como ya vimos- es algo que puede dejar poco lugar a dudas. Sobre todo después de leer testimonios del propio Wittgenstein como el del 13 de enero de 1922 que acaba de publicarse en castellano, cito in extenso:

Esta noche tuve una extraña vivencia. Comenzó así: soñé que mi hermana Mining, en cierta circunstancia (que he olvidado), me hacía una observación lisonjera sobre mi capacidad intelectual (en un sentido laudatorio para mí, decía algo así como: "Ahí se ve precisamente la diferencia entre los espíritus"). Es verdad que rechacé esa posición singular, defendiendo a los otros que Mining colocaba a un nivel inferior, pero en el fondo me alegró la lisonja y el reconocimiento de mi espíritu superior. A continuación me desperté, avergonzándome de mi envanecimiento y mi vulgaridad, y movido por una especie de arrepentimiento... hice la señal de la cruz. Sentí que debía acompañar ese gesto incorporándome, al menos, en la cama, o arrodillándome, pero fui demasiado vago para ello e hice la señal de la cruz semiincorporado y me recosté de nuevo. Pero entonces sentí que debía levantarme, que Dios exigía eso de mí... Tras alguna resistencia, seguí la orden, di la luz y me levanté. Allí estaba, de pie, en la habitación, con una sensación horrorosa. Fui hacia el espejo, me vi en él y mi imagen me miraba tan espantosamente que oculté mi rostro entre las manos... No tenía permiso para volver a la cama, pero me temía nuevas órdenes e, incumpliendo la que tenía, como un mal soldado, como un desertor, me fui a la cama lleno de un temor horrible... Así permanecí algún tiempo, con una sensación horrible, temiendo dormirme no fuera que en sueños me viniera con plena claridad toda mi situación a la conciencia y tuviera que tomar sobre mí lo más horrible... Como he dicho, hoy durante la noche me he dado cuenta de mi completa inanidad. Dios se ha dignado mostrármela. Mientras sucedía todo, he pensado continuamente en Kieerkegaard $\mathrm{y}$ he creído que mi estado era el de temor y temblor. ${ }^{37}$

${ }^{37}$ L. Wittgenstein, Luz y sombra. Una vivencia(-sueño) y un fragmento epistolar, pp. 28-30. Wittgenstein debía tener más o menos recurrentemente este tipo de sueños. En Movimientos del pensar se encuentra el relato de otro —en el que también estaba involucrada su hermana Mining - y en el que de nuevo la vanidad —esta vez a cuenta de sus "increíbles dotes musicales"- vuelve a ser el motivo central. Resulta de lo más significativa la invocación con la que Wittgenstein finaliza el relato del sueño: “iOjalá no me vuelva vulgar del todo, ni loco tampoco! Quiera Dios tener misericordia de mí” (op. cit., p. 101). Por lo demás, vale la pena recordar el testimonio de Bunyan, con cuyo estado compara James el suyo propio: "Me encontraba invadido por un gran temblor, de forma que, a veces, durante algunos días, podía sentir mi cuerpo, así como mi mente, temblando y tambaleándose bajo 
La experiencia religiosa era entonces, para Wittgenstein - convendría tomar nota de ello-, una experiencia del más terrible sufrimiento espiritual; por así decirlo, la experiencia en la que tocaba fondo y se hacía consciente de su completa inanidad, una experiencia claramente enfermiza que lo hacía sentirse absolutamente miserable a los ojos de Dios. ${ }^{38}$ Pero, quizá por ello mismo, también la única experiencia que podía servirle de catarsis de su vanidad; la experiencia que podía poner fin a la infinita espiral viciosa ${ }^{39}$ por la que incluso el propósito de poner coto a su vanidad podía resultarle sospechosa de vanidad:

Es difícil entenderse bien uno mismo, pues lo que se podría hacer por magnanimidad y bondad, puede hacerse también por cobardía o indiferencia. Es posible comportarse de tal o cual modo por verdadero amor, pero también por astucia y frialdad de corazón. Como no toda humildad es bondad. Y sólo si pudiera hundirme en la religión, podrían acallarse estas dudas. Pues sólo la religión podría destruir la vanidad y penetrar en todas las hendiduras. ${ }^{40}$

En cierta manera, la experiencia religiosa de Wittgenstein supone una inversión tan cabal del cartesianismo como lo suponen sus reflexiones epistemológicas — con las que, después de todo, quizá estén conectadas- ${ }^{41} \mathrm{Si}$ para Descartes la certeza intelectual que el yo tiene de sí mismo destruye una duda hiperbólica pero a la postre ficticia, y se constituye en la verdad fundamental a partir de la cual se puede demostrar metafísicamente la existencia de un Dios garante de la racionalidad del mundo, para Wittgenstein la certeza moral de la existencia

la sensación del terrible juicio de Dios..." (Las variedades de la experiencia religiosa, p. 226, nota 18).

38 "Los hombres son religiosos no tanto en cuanto se creen muy imperfectos sino en cuanto se creen enfermos. Cualquier persona medianamente decente se considerará sumamente imperfecta; pero el hombre religioso se considera miserable" (Aforismos. Cultura y valor, aforismo 501).

39 "La religión cristiana es sólo para aquel que necesita una ayuda infinita, es decir, para quien siente una angustia infinita" (ibid., aforismo 504). El conjunto de esta reflexión, con la que se cierra la selección, resulta a la vez espeluznante y extremadamente clarificador de lo que Wittgenstein esperaba de la religión.

${ }^{40}$ Ibid., a forismo 271.

${ }^{41}$ N. Malcolm ya percibió esta conexión en Wittgenstein: A Religious Point of View? En resumidas cuentas, Malcolm entiende que el escepticismo de fundamentación - la falta de fundamento de las certezas que yacen a la base de nuestras creencias fundadas- constituye la principal base de la analogía entre las tesis epistemológicas wittgensteinianas y su concepción de la creencia religiosa. 
de Dios, una certeza absolutamente irracional e infundada, ${ }^{42}$ es la que pone fin a una duda angustiosamente vivida que amenazaba con destruir cualquier confianza en sí mismo. Lo que une a ambos pensadores es la necesidad imperiosa de una certeza inconcusa; el que ni uno ni otro pudieran pasarse sin una certeza inconmovible acerca del mundo o del yo. Justo aquello que Hume acertó a hacer.

\section{La gran iniciación}

Wittgenstein podía haber tomado su buena dosis de pesimismo de Schopenhauer. Pero, como apunta James a propósito de este filósofo alemán, lo mismo que a propósito de su discípulo de primera hora, Nietzsche, en él sólo se encontraba el pesimismo malhumorado. Faltaba la esperanza que sólo la experiencia religiosa podía proporcionar. ${ }^{43}$ Justamente una esperanza que Wittgenstein bien pudo confirmar en el libro de James. Y digo confirmar porque, al fin y a la postre, cuando Las variedades de la experiencia religiosa cayeron en las manos de Wittgenstein, éste ya había recobrado una fe religiosa que previamente había perdido, según parece a resultas de sus conversaciones con su hermana Margarethe (quien, por cierto, le había introducido en la lectura de Schopenhauer). ${ }^{44}$

${ }^{42}$ Los testimonios que demuestran que Wittgenstein hacía una interpretación absolutamente irracionalista y fideísta del cristianismo que él abrazaba, lectura indiscutiblemente influida por Kierkegaard, son abrumadores. A modo de compendio baste esta observación, la 476, de Aforismos. Cultura y valor: "Si el cristianismo es la verdad, es falsa toda filosofía al respecto."

43 "El humor de un Schopenhauer o de un Nietzsche [...], aunque a menudo sea una tristeza ennoblecida, es con frecuencia sólo malhumor y evasión descontrolada [...]. Les falta la nota purgativa que destila la tristeza religiosa" (Las variedades de la experiencia religiosa, p. 70). En la última conferencia de Pragmatismo. Un nuevo nombre para antiguos modos de pensar, James contrapone la posición del filósofo alemán, a quien reputa como introductor del pesimismo, con su meliorismo pragmatista ( $c f r$. p. 181). A propósito de Schopenhauer, por quien no obstante se reconocía influido, escribe Wittgenstein: "Podría decirse que Schopenhauer es un espíritu muy tosco. Es decir, tiene refinamiento, pero a cierta profundidad éste termina de pronto y es tan tosco como el que más. Allí donde empieza la verdadera profundidad, termina la suya. Podría decirse que Schopenhauer nunca entra en sí mismo" (Aforismos. Cultura y valor, aforismo 190). Lo que ahora sabemos es que cuando Wittgenstein entraba en sí mismo, lo que hallaba era una angustia abismal que sólo Dios podía curar.

${ }^{44}$ Por cierto que la constatación de este hecho podría servir para despejar una duda que legítimamente podría plantearse; a saber: la de si a la postre no sería la propia religión la que habría inducido en Wittgenstein la melancolía de la que

Diánoia, vol. LII, no. 59 (noviembre 2007). 
En efecto, suele datarse hacia principios de $1911^{45}$ la fecha en que Wittgenstein asistió a la representación de la obra de Ludwig Anzengruber, Die Kreuzelschreiber (Los que firman con una cruz), en la que el personaje central pronuncia una frase que para Wittgenstein había de convertirse en el detonante de una experiencia mística a la que luego habría de referirse en su conferencia sobre ética. La frase en cuestión era: "Tú formas parte del todo, y el todo forma parte de ti. iNo puede ocurrirte nada!" La experiencia: la de sentirse absolutamente a salvo. ${ }^{46}$

$\mathrm{Si}$ antes vimos cómo Wittgenstein pudo reconocerse en la descripción del alma enferma que James proporcionaba en las conferencias VI y VII de su libro, podemos entender ahora que se sintiera todavía más identificado a medida que proseguía la lectura del mismo. Al fin y al cabo, él era uno de esos conversos, de esos nacidos dos veces, de los que se hablaba a continuación de haberse caracterizado la personalidad mórbida. Y, además, un renacido gracias a una experiencia mística en la que James, a pesar de admitir su incapacidad para experimentarla, situaba la "raíz y el centro" de la religión tal y como él la entendía. ${ }^{47}$ Cabía, pues, mejorar. Y para ello había que proponerse la santidad como ideal, aunque sólo fuera regulativo. Pero, ¿qué implicaba la santidad?

El autor de Las variedades de la experiencia religiosa le dedica nada menos que cinco conferencias, tres a caracterizarla y dos a valorarla. No vamos ni siquiera a intentar resumir sus tesis al respecto; nos conformaremos con señalar algunos rasgos especialmente llamativos de estas tesis cuando se leen pensando en Wittgenstein.

James define la santidad como "el nombre común para los frutos maduros de la religión en el carácter"; "el carácter santo —nos dicees aquel para el cual las emociones espirituales son el centro habitual de la energía personal, y existe una panorámica compuesta por la san-

la religión prometía redimirle. En su caso no era así. Como sabemos por, entre otras cosas, las anotaciones de Pinsent en su diario, Wittgenstein ya padecía de una melancolía acusada desde mucho antes de que volviera a recobrar la fe infantil que había perdido. Cfr. G.H. von Wright, Retrato del joven Wittgenstein, pp. 32-33.

${ }^{45}$ No obstante, Monk aduce razones bastante plausibles para situar la fecha de la conversión de Wittgenstein en la Semana Santa de 1912. Cfr. R. Monk, Ludwig Wittgenstein. El deber de un genio, p. 63, nota 1.

${ }^{46} \mathrm{Cfr}$. L. Wittgenstein, Conferencia sobre ética, p. 39. Nótese que esta experiencia mística cauteriza el tipo de melancolía de la que "el paciente francés" de William James estaba aquejado. Por lo demás, el lance es descrito con cierto detalle por W. Baum. Ludwig Wittgenstein. Vida y obra.

${ }^{47}$ Cfr. Las variedades de la experiencia religiosa, p. 507. 
tidad universal, la misma para todas las religiones". ${ }^{48}$ A continuación enumera una serie de características de la santidad que podríamos resumir diciendo que la santidad significa un rechazo del egoísmo, una sensibilidad expansiva, alegre, afirmativa, y una rendición de la propia voluntad a lo que se considera la voluntad superior de Dios. ${ }^{49} \mathrm{~A}$ su vez, estas características del carácter santo conllevan toda una serie de consecuencias prácticas, como el ascetismo, la fortaleza del alma, la pureza, la caridad; ${ }^{50}$ y en la tradición de la Iglesia cristiana, la obediencia, la pobreza, la castidad... ${ }^{51}$

Para mí resulta del todo evidente que a partir de 1913 Wittgenstein empezó a orientar su vida movido por este ideal de santidad. ${ }^{52}$ A la luz de esta hipótesis, de hecho, creo que cobran luz muchos de sus comportamientos que de otro modo pueden parecer pura y simple extravagancia.

Los diarios secretos de la guerra, por ejemplo, testimonian constantemente los esfuerzos de Wittgenstein para hacer del espíritu el destinatario de toda su energía personal, ${ }^{53}$ para rendir su voluntad a lo que el

${ }^{48}$ Las variedades de la experiencia religiosa, pp. 366-367. Es importante darse cuenta de que para James los rasgos del carácter santo vienen a ser comunes a todas las religiones - es decir, son transculturales-. Otro tanto ocurre con el misticismo. Y digo que es importante porque Gellner reprochó a Wittgenstein justamente su ceguera para la diversidad cultural que se encierra por debajo del término "mística" (cfr. Lenguaje y soledad, pp. 124-126). Posiblemente se trate de una pseudocuestión - al fin y al cabo, que veamos los fenómenos como iguales o como diferentes depende de cuál sea el criterio con que los comparemos, de forma que podemos decir tanto que el misticismo es esencialmente el mismo en todas las culturas como que es tremendamente diferente en cada una de ellas-. Lo relevante para nosotros es que muy posiblemente Wittgenstein estuvo influido por James en su concepción "acultural" de lo místico.

${ }^{49}$ Cfr. Las variedades de la experiencia religiosa, pp. 368-369.

${ }^{50}$ Cfr. ibid., pp. 369-371. Por lo demás, sólo resta decir que James hace de todas estas consecuencias —el ascetismo incluido - una interpretación claramente positiva. Caben, evidentemente, interpretaciones alternativas de ellas. El ascetismo, por ejemplo, puede considerarse autodestructivo. Y la caridad, como no se le escapa al propio James, puede resultar contraproducente.

${ }^{51}$ Cfr. ibid., p. 418.

${ }^{52}$ Recuérdese que Russell databa en el invierno que Wittgenstein pasó en Noruega — para la que partió a comienzos de octubre de 1913- el origen de su misticismo.

53 “Una y otra vez me repito interiormente las palabras de Tolstoi: 'El hombre es impotente en la carne, pero libre gracias al espíritu.' iOjalá que el espíritu esté en mí!" (Diarios secretos, observación del 12 de septiembre de 1914). Resulta, por lo demás, conmovedora la confesión de las dificultades que Wittgenstein encuentra para consagrarse únicamente a la vida del espíritu: "Resulta infinitamente difícil

Diánoia, vol. LII, no. 59 (noviembre 2007). 
destino - la voluntad de Dios - le quiera deparar, ${ }^{54}$ para obedecer sin más; ${ }^{55}$ en definitiva, para lograr esa exultación que el santo es capaz de encontrar en la vida a pesar de sus adversidades. ${ }^{56}$ Pero incluso la manera en que Wittgenstein afrontó el acontecimiento bélico creo que queda iluminada si tenemos en cuenta su aspiración a la santidad.

En efecto, vista desde fuera la reacción de Wittgenstein parece un poco extraña. Si su primera intención, al enterarse del estallido de la guerra, fue intentar salir de Austria para marchar a Inglaterra (iInglaterra!) o Noruega, cuando tal empeño le resultó imposible se alistó como voluntario en el ejército austriaco, en el cual combatiría con gran heroísmo.

Desde luego, aun si Wittgenstein se identificaba, como ya dijimos, con la causa germánica, sus motivos no pudieron ser sólo patrióticos (¿qué patriota pensaría en huir al país enemigo?) y sus diarios dejan traslucir que su comprensión de la guerra era bastante personal, ${ }^{57}$ así

resistirse siempre al mal. Es difícil servir al espíritu con el estómago vacío y sin haber dormido" (Diarios secretos, observación del 18 de septiembre de 1914).

54 "Una sola cosa es necesaria: ser capaz de ver como un espectador todo lo que le ocurre a uno. iRECOGERSE! iQue Dios me ayude!" (Diarios secretos, observación del 25 de agosto de 1914). "De nuevo algo sensual. iVivir sólo para el espíritu y dejar todo en manos de Dios!" (Diarios secretos, observación del 30 de noviembre de 1914). "Tengo que entregarme completamente a mi destino!" (Diarios secretos, observación del 25 de enero de 1915). Un propósito, de nuevo, que le resulta extremadamente difícil de cumplir: "Sigo sin realizar plenamente mi propósito de pasividad total" (Diarios secretos, observación del 29 de agosto de 1914); "Cuando estoy cansado y tengo frío, enseguida pierdo, por desgracia, el ánimo para soportar la vida tal como es. Pero me esfuerzo en no perderlo" (Diarios secretos, observación del 8 de octubre de 1914).

55 "En mí alternan momentos de indiferencia respecto al destino externo, con otros en que vuelvo a anhelar la tranquilidad y la libertad externa, en que estoy cansado de tener que ejecutar dócilmente cualquier orden" (Diarios secretos, observación del 12 de octubre de 1914).

56 “¿Cómo he de vivir, por tanto, para salir airoso en cada instante? Vivir en lo bueno y en lo bello hasta que la vida acabe por sí misma" (Diarios secretos, observación del 7 de octubre de 1914). La alegría como un favor de Dios y también como un mandato: "En suma, hay momentos en que soy incapaz de vivir meramente en el presente y sólo para el espíritu. Las horas buenas de la vida debemos disfrutarlas con gratitud, como una gracia y, por lo demás, ser indiferentes con respecto a la vida". (Diarios secretos, observación del 12 de octubre de 1914); "No me siento bien, no tengo verdaderas ganas de vivir". (Diarios secretos, observación del 19 de octubre de 1914). "Pero mi espíritu habla dentro de mí contra mis depresiones. Dios sea conmigo". (Diarios secretos, observación del 20 de octubre de 1914).

${ }^{57}$ A propósito de su amigo David Pinsent, se preguntaba Wittgenstein: "i¿concebirá él la guerra de una manera más personal que yo?!" (Diarios secretos, obser- 
como su incredulidad con respecto a la dimensión colectiva de la misma. De hecho, recién alistado comenta a propósito de sus compañeros de destino en el Goplana, el barco en el que Wittgenstein empezó a prestar servicio: "iLa tripulación del barco es una banda de cochinos! iDe entusiasmo, nada, e increíbles su grosería, su estupidez y su maldad! Por tanto no es cierto que la gran causa común ennoblezca necesariamente a las personas." 58

Pero ¿qué tipos de motivos personales podía tener Wittgenstein para ir voluntariamente a la guerra? Aquí es donde algunas observaciones de James creo que pueden resultar iluminadoras. Evaluando las virtudes religiosas —de las que, como de todo tipo de pasión, ya había dicho que incrementaban el valor- ${ }^{59}$ escribe:

Si alguien alguna vez ha percibido claramente en su mente el hecho de la presencia de la muerte trágica en la historia de este mundo - congelación, muerte por ahogo, enterramiento en vivo, devorado por bestias salvajes, en manos de criminales y las enfermedades más espantosas-, me parece que con dificultad puede continuar su propia vida de prosperidad mundana sin sospechar que mientras tanto quizás no esté realmente dentro del juego, puesto que le falta la gran iniciación.

Pues bien, eso es exactamente lo que sostiene el ascetismo y toma la iniciación voluntariamente. La vida no es ni una farsa ni una comedia elegante, afirma, sino algo que hemos de contemplar con vestidos de luto, esperando que su sabor amargo nos purgará de nuestra locura. La insensatez y el heroísmo son partes de ella tan enraizadas que la mentalidad sana, pura y simple, con su optimismo sentimental, difícilmente puede ser contemplada por ningún hombre sensato como una solución seria. Las fra-

vación del 13 de diciembre de 1914). Monk, quien igualmente defiende el sentido personal que la guerra revestía para Wittgenstein, cita el testimonio de su hermana Hermine en este mismo sentido. Cfr. R. Monk, Ludwig Wittgenstein. El deber de un genio, p. 117. También conviene tener presente lo que dice Isidoro Reguera al respecto en su epílogo a Los diarios secretos: "Cuadernos de guerra".

${ }^{58}$ Diarios secretos, observación del 15 de agosto de 1914. De hecho, la maldad y la vulgaridad de sus propios camaradas de armas se convierte en el principal motivo de mortificación para Wittgenstein durante la guerra (como antes lo fue la de sus camaradas de escuela: "Ahora llegará para mí un período enormemente difícil, pues de hecho ahora vuelvo a estar tan vendido y traicionado como lo estuve en otro tiempo en la escuela de Linz" (Diarios secretos, observación del 22 de agosto de 1914), como sería siempre la vulgaridad, a su entender, de la mayor parte de la gente con la que se encontraba la que lo condenaba a experimentar una profunda soledad.

59 "Lo más importante que una gran pasión proporciona es el valor..." (Las variedades de la experiencia religiosa, p. 359, nota 4).

Diánoia, vol. LII, no. 59 (noviembre 2007). 
ses de consuelo elegantes y reconfortantes nunca pueden ser una respuesta al enigma de la esfinge.

En estas observaciones me baso sencillamente en el común instinto de realidad de la humanidad que de hecho siempre ha mantenido que el mundo es esencialmente un teatro para el heroísmo. En el heroísmo percibimos que se oculta el supremo misterio de la vida. No toleramos a nadie que no tenga capacidad para el heroísmo en algún aspecto. Por otra parte, no nos importan las debilidades de un hombre si está deseoso de arriesgarse hasta la muerte y aún más, si la padece heroicamente en la causa que ha elegido; este hecho lo consagrará para siempre... Cada uno de nosotros siente personalmente que la indiferencia magnánima hacia la vida expiaría todos sus defectos. ${ }^{60}$

De hecho, es en esta congruencia profunda con la naturaleza humana, con ese "común instinto de realidad de la humanidad", donde estriba para James "la belleza de la guerra". ${ }^{61}$

Pues bien, volviendo ahora a Wittgenstein, si no podía sustraerse a la guerra huyendo a Noruega o Inglaterra - y esta frustrada huída ya apuntaría que al fin y al cabo para él, como para James y a diferencia de Nietzsche, ${ }^{62}$ la guerra no era una dedicación realmente noble-, tendría que acatar la voluntad de Dios, su destino; aceptaría voluntariamente la gran iniciación. Conocería de primera mano la muerte e intentaría afrontarla heroicamente. ${ }^{63}$

En resumidas cuentas, las razones de Wittgenstein para ir a la guerra no eran especialmente patrióticas (por más que se identificara con su patria "alemana"), no eran tampoco ningún entusiasmo bélico. Eran razones fundamentalmente religiosas. Su heroísmo no era una virtud aristocrática sino ascética. A diferencia del de muchos de sus contemporáneos, tenía muy poco de nietzscheano y mucho de jamesiano.

\footnotetext{
${ }^{60}$ Ibid., pp. 487-488; las cursivas son mías.

${ }^{61}$ Cfr. ibid., p. 490.

${ }^{62}$ Wittgenstein leyó a Nietzsche durante la guerra. Cfr. Diarios secretos, observación del 8 de diciembre de 1914.

63 "No tengo miedo a que me maten de un tiro, pero sí a no cumplir correctamente con mi deber. iQue Dios me dé fuerzas! Amén. Amén. Amén" (Diarios secretos, observación del 12 de septiembre de 1914). "Ahora se me presentaría la ocasión de ser una persona decente, pues me enfrento cara a cara a la muerte. iQue el espíritu me ilumine!" (Diarios secretos, observación del 15 de septiembre de 1914).
} 
8. La religión como crítica de la sociedad

En cualquier caso, el ascetismo -y su vástago, el heroísmo- no era la única virtud que el ideal de santidad hacía perseguir a Wittgenstein. También estaban la pureza — de la que luego algo diremos-y la pobreza.

Aparte de la concomitancia por lo que se refiere al heroísmo, ya James había señalado otra coincidencia entre el santo y el guerrero aristócrata. En efecto, aunque los caballeros - apunta el filósofo norteamericano- ejercieron de depredadores de tierras y bienes, no cifraban en estas posesiones la esencia de su superioridad personal. Para ellos era más importante lo que eran —orgullosos, valientes, generosos... - que lo que tuvieran. Más importante ser que tener. Una valoración en la que coincidían con los santos (y icon el trabajador y su odio al capital!), ${ }^{64}$ pues "Resumiendo, las vidas basadas en la posesión son menos libres que las que se fundamentan en ser o en hacer; y en interés de la acción, la gente presa del entusiasmo espiritual arroja las posesiones e impedimentos." 65

Pues bien, como es bien sabido, una vez terminada la guerra, Wittgenstein legó todo su capital, heredado a la muerte de su padre, a sus hermanos, suficientemente ricos ya como para no resultar corrompidos por el dinero. Russell no duda en relacionar este gesto de Wittgenstein con su misticismo:

Ha penetrado profundamente en los modos místicos de pensamiento y sentimiento - le escribe a Lady Ottoline-... No creo que realmente se haga monje; es una idea, no una intención. Su intención es ser maestro. Dio todo su dinero a sus hermanos y hermanas, porque considera que las posesiones terrenales son una carga. ${ }^{66}$

Hay, por lo demás, otro aspecto interesante en este asunto que es el que ahora quisiera subrayar. Para ello es preciso volver a James. Éste, en su defensa de la santidad, se ve en la obligación de hacerse cargo de las acusaciones que contra las virtudes religiosas o virtudes monacales, como las denominaba Hume ${ }^{67}$ habían lanzado los librepensadores ilustrados - aunque en realidad la crítica de estas virtudes ya se puede encontrar antes; por ejemplo en algunos círculos del humanismo

${ }^{64}$ Cfr. Las variedades de la experiencia religiosa, pp. 427-428.

${ }^{65}$ Ibid., p. 429.

${ }^{66}$ Wittgenstein, Cartas a Russell, Keynes y Moore, p. 76.

${ }^{67}$ Cfr. D. Hume, Investigación sobre los principios de la moral, sección IX, parte I, pp. 142-143.

Diánoia, vol. LII, no. 59 (noviembre 2007). 
cívico- En esencia la acusación era doble, aparte del sufrimiento que provocan en quien las tiene (o padece, según este punto de vista), carecen de toda utilidad social (si es que no resultan lisa y llanamente contraproducentes).

James no niega sin más estas acusaciones. ${ }^{68}$ Por una parte, concede que las virtudes santas pueden, si son excesivas, conducir al fanatismo y a conductas, por ejemplo de mortificación corporal, difícilmente aceptables por su extravagancia. Por la otra, concede igualmente que en el pasado la santidad no siempre ha tenido una utilidad social. Ha habido una santidad tonta ${ }^{69}$ que obedece a la falta de inteligencia de algunos santos —el caso de la bienaventurada Margarita María Alacoque-, ${ }^{70}$ y otra que podríamos calificar de idiota debida a la escasa sensibilidad social de otros —el caso de nuestra santa Teresa- $-{ }^{71} \mathrm{Y}$ cuando esa preocupación social ha estado presente, a veces ha pecado de un exceso igualmente pernicioso. ${ }^{72}$

Pero que esto haya ocurrido a veces, no significa para James que haya ocurrido siempre ni que tenga por qué ocurrir en el futuro. Las virtudes del santo no tienen por qué caer en el exceso, ni por tanto en el fanatismo; y cuando no sucede así, la opinión de James es que la religiosidad proporciona una alegría vital y una felicidad que difícilmente podría conseguirse de ninguna otra manera. Y esas mismas virtudes han tenido, y sobre todo pueden tener, una virtualidad social.

En efecto, no es sólo que la caridad del santo al tratar como digno al malvado haya conseguido dignificarlo, regenerando a seres humanos de cuya dureza en principio hacía que poco pudiéramos esperar, ${ }^{73}$ o que esa misma caridad haya sido el anuncio de un cambio de la sensibilidad

68 "Así, cuando los librepensadores afirman que la religión y el fanatismo son gemelos, no podemos aducir una negación incondicional de la acusación" (Las variedades de la experiencia religiosa, p. 460).

${ }^{69}$ Cfr. ibid., p. 502 nota 25.

${ }^{70}$ Cfr. ibid., p. 460.

${ }^{71}$ Cfr. ibid., p. 465-466.

${ }^{72}$ Véase ibid., pp. 475 y 477 :

Siguiendo adelante en la investigación de la extravagancia religiosa, llegamos a los excesos de ternura y de caridad [...]. Francamente hemos de confesar... que en el mundo actual las virtudes de simpatía, caridad y pasividad pueden ser, y con frecuencia lo han sido, exhibidas en exceso... Toda la organización científica moderna de la caridad es una consecuencia sencilla del fracaso de dar limosna.

${ }^{73}$ Cfr. ibid., p. 478. 
moral, hasta hacernos más intolerantes para la brutalidad del castigo o la pena de muerte. ${ }^{74}$ Es, sobre todo, que algunas de las virtudes religiosas sirven de eficaz denuncia de algunos rasgos defectuosos de nuestra civilización. El ascetismo, por ejemplo, debiera hacer pensar en la debilidad de carácter que un sistema educativo excesivamente laxo genera (y recuérdese que, después de la guerra, Wittgenstein no sólo renunció a toda su riqueza, sino que además empezó a trabajar como maestro, bastante exigente por cierto):

La manera exclusivamente despreocupada y evasiva de educar a la mayoría de los niños de hoy - tan diferente de la educación de hace cien años, especialmente en círculos evangélicos- ¿no corre el peligro, pese a sus numerosos avances, de desarrollar una cierta inutilidad de carácter? ¿No emergen por aquí algunos puntos de aplicación para una disciplina ascética renovada y corregida? ${ }^{75}$

Pero si en alguna virtud religiosa ve James, más que en ninguna otra, una potencialidad crítica para con nuestra civilización, ésa sin duda es la pobreza. No me resisto a citarlo por extenso:

El propósito inmediato de la vida del soldado es [...] la destrucción [...]. Sin embargo, persiste el hecho de que la guerra es una escuela de la vida esforzada y del heroísmo, y al estar en la línea del instinto primigenio, es la única escuela que es de momento universalmente asequible. Pero cuando nos preguntamos seriamente si esta organización a gran escala de la irracionalidad y del crimen sería nuestro único parapeto contra el afeminamiento, nos horrorizamos sólo de pensarlo [...]; hemos de descubrir [...] en el reino social [...] el equivalente moral de la guerra, algo heroico que hable a los hombres tan universalmente como lo hace la guerra [...], tan compatible con su yo espiritual como la guerra es de incompatible. Frecuentemente, he pensado que en el antiguo culto de la pobreza monástica [...] debía haber alguna cosa parecida a este equivalente moral a la guerra que buscamos. ¿No podría ser que la pobreza aceptada voluntariamente fuese "la vida esforzada", sin necesidad de aplastar a la gente más débil?

En realidad, la pobreza es la vida esforzada, sin fanfarrias ni uniformes ni aplausos populares histéricos, ni mentiras ni circunloquios. Cuando se ve de qué forma el deseo de riqueza penetra como ideal hasta la médula de nuestra generación, uno se pregunta si un renacimiento de la creencia de que la pobreza es una vocación religiosa que vale la pena no implicaría

${ }^{74}$ Cfr. ibid., p. 479. Dicho sea de paso, los argumentos de James no parecen haber hecho mucha mella en los actuales neoconservadores cristianos estadounidenses.

${ }^{75}$ Ibid., p. 489.

Diánoia, vol. LII, no. 59 (noviembre 2007). 
"la transformación del valor militar" y la reforma espiritual que nuestro tiempo está necesitando más.

Entre los pueblos de habla inglesa, especialmente, vuelve a ser necesario que se entonen con valentía alabanzas de la pobreza. Hemos crecido literalmente temiendo ser pobres. Menospreciamos a cualquiera que elige la pobreza... Si una persona no se une a la lucha y al anhelo general por hacer dinero, la consideramos sin espíritu y sin ambición. Incluso hemos perdido el poder de imaginar lo que la antigua idealización de la pobreza podía haber significado: la liberación de las ataduras materiales, el alma insobornable, la indiferencia viril hacia el mundo; resolver las propias necesidades por lo que se es o se hace y no por lo que se posee... Cuando los que pertenecemos a las llamadas clases superiores quedamos horrorizados, como ningún hombre en la historia lo ha estado, de la dureza y fealdad material, cuando aplazamos el matrimonio hasta que la casa pueda estar bien decorada y temblamos con el solo pensamiento de tener un hijo sin poseer una cuenta saludable en el banco, es el momento para que los pensadores protesten contra un estado de opinión tan poco humano e irreligioso... Recomiendo que meditéis seriamente sobre este tema, ya que es seguro que el temor a la pobreza que prevalece en las clases cultas es la enfermedad moral más grave que padece nuestra civilización. ${ }^{76}$

Si una larga estela de pensadores, empezando por Maquiavelo, pasando por Hume y culminando en Marx, hicieron de la sociedad y de sus intereses la piedra de toque para la crítica de la religión, James invierte el planteamiento y hace de la religión la piedra de toque de la crítica de la sociedad.

¿Le siguió en esto Wittgenstein? Bueno, lo que es seguro es que renunció voluntariamente a la riqueza, muy probablemente, si hemos de creer a Russell, por motivos religiosos. Y lo que es también seguro es que se le hacía insoportable el espíritu burgués, ${ }^{77}$ y que así mismo veía en la religión un factor de nivelación, de igualdad entre los hombres:

Quien abre su corazón a Dios, así, en arrepentida confesión, se abre también a los otros. Pierde, con ello, su dignidad de hombre reconocido haciéndose, por tanto, como un niño. Es decir, sin posición social, dignidad

${ }^{76} \mathrm{Ibid}$., pp. 491-494. El texto es sumamente interesante. James prosigue una vieja tradición cuyos orígenes podríamos, como mínimo, remontar hasta la República platónica, que conecta el afán de riqueza con el militarismo. Por otra parte, no debiéramos olvidarnos de una tradición que, frente a Marx, quien pensaba en el socialismo como una formación social de mayor opulencia todavía que el capitalismo, defendió que la nueva sociedad debería basarse en una moral de la austeridad - Gramsci, por ejemplo-.

${ }^{77} \mathrm{Al}$ respecto, remito a mi trabajo "Una filosofía del espíritu. Wittgenstein y la cuestión judía", p. 294. 
y diferencia de los demás. Sólo se puede abrir uno a los demás desde una especial forma de amor: la que reconoce, por así decirlo, que todos somos unos niños malos. ${ }^{78}$

\section{A modo de conclusión provisional: la filosofía como acto religioso}

Con su libro, James perseguía fundamentalmente dos objetivos. Por una parte, defender la "experiencia" por oposición a la "filosofía" como columna vertebral de la religión. Por la otra, convencer al lector de que aunque todos sus credos y teorías han sido absurdas, la religión constituye la más importante función de la humanidad. Tarea que él consideraba prácticamente imposible pero en la que estaba empeñado dado que la consideraba como un acto él mismo religioso. ${ }^{79}$ De modo que bien podría decirse que Las variedades no sólo es un libro sobre la religión, sino un libro él mismo religioso. De hecho, no podría ser de otro modo, dado que, para James, "Todo el hombre dentro de nosotros es el que está trabajando cuando formamos nuestras opiniones filosóficas. El intelecto, la voluntad, el gusto y la pasión cooperan justamente como lo hacen en los asuntos prácticos..." 80

Wittgenstein participaba de esta concepción vital de la filosofía. ${ }^{81}$ Para él, la filosofía no era una doctrina, sino una actividad en la que, por decirlo a la manera de James, se comprometía todo él. Y ahora podemos entender la observación a Drury con la que prácticamente empezábamos nuestro trabajo. No se puede ser un buen filósofo sin ser un auténtico ser humano. Al fin y al cabo, ésta, la de mejorarse uno a sí mismo, es la única función que la filosofía podía tener según Wittgenstein.

En todo esto la filosofía se parece a la religión tal y como la entendía Wittgenstein. Tampoco ésta es, para él, una doctrina, sino una forma de vida. Y una forma de vida que debiera servir para hacerle mejor. Pero no voy a entrar aquí en la filosofía de la religión del pensador austriaco, una filosofía que, como la de James, él elaboró sin duda a partir de su propia experiencia religiosa. Es éste un tema que necesariamente debe quedar para otro trabajo.

${ }^{78}$ Aforismos. Cultura y valor, observación 504.

${ }^{79} \mathrm{Cfr}$. la carta a Frances Morse del 12 de abril de 1900, The Letters of William James, vol. II, p. 215.

${ }^{80}$ W. James, The Will to Believe and Other Essays on Popular Philosophy, p. 92.

81 "Mis problemas personales aparecen en la filosofía que escribo" (K. Wuchterl y A. Hübner, Ludwig Wittgenstein in Selbstzeugnissen und Bilddokumenten, p. 67).

Diánoia, vol. LII, no. 59 (noviembre 2007). 
Lo que quiero apuntar aquí, ya para terminar, es que, en mi opinión, bien se puede decir que la filosofía tenía para Wittgenstein mucho de acto religioso. O mejor, más que apuntar, apuntalar, pues ya en un trabajo anterior defendí esta idea. ${ }^{82}$ Pero pensar la filosofía de Wittgenstein contra el trasfondo de la obra de James creo que refuerza esta hipótesis hermenéutica. Veamos.

Decía allí que de la filosofía wittgensteiniana podíamos decir que era religiosa por su objetivo: una crítica de la civilización en nombre de la cultura. Pero lo que ahora hemos visto es que, como James, la crítica de la civilización bien la pudo hacer Wittgenstein en nombre de ciertas virtudes claramente religiosas, como la pobreza.

Decía también allí que la filosofía era para Wittgenstein una actividad religiosa por su origen: el entusiasmo, la participación en un espíritu que el autor del Tractatus solía interpretar en términos de inspiración. Y ahora podríamos no sólo completar las referencias que allí se daban con las innumerables observaciones de sus diarios en que Wittgenstein implora un "pensamiento redentor" y habla de su trabajo como una "gracia" divina, sino comprender que no se trata de retórica, pues para Wittgenstein la tranquilidad del espíritu, la cura del desasosiego, de la Sorge, objetivo último de la filosofía, ${ }^{83}$ no podía venir, dada su identificación con el retrato jamesiano del alma enferma, sino de una experiencia religiosa.

Hablaba igualmente de la dimensión ética y estética de su pensamiento, ética y estética que Wittgenstein entendía como estrechamente relacionadas con la experiencia de Dios; y a este respecto sugería la posible naturaleza musical del Tractatus, con sus siete proposiciones correspondiéndose con las siete notas de la escala. Lo que ahora podríamos añadir es que el Tractatus era para Wittgenstein, en última instancia, el fruto de una experiencia mística y él mismo una obra mística, y que como apunta James, "muchos textos místicos son, de hecho, apenas otra cosa que composiciones musicales". ${ }^{84}$

\footnotetext{
${ }^{82}$ El ya aludido "Una filosofía del espíritu. Wittgenstein y la cuestión judía".

83 "La tarea de la filosofía es tranquilizar el espíritu con respecto a preguntas carentes de significado. Quien no es propenso a tales preguntas no necesita la filosofía" (Movimientos del pensar, p. 52). En ese mismo diario escribe Wittgenstein: "Liberarse de los sufrimientos del espíritu, eso significa liberarse de la religión" (p. 116).

${ }^{84}$ Las variedades de la experiencia religiosa, p. 563. James cita en este punto a Helena Petrovna Blavatsky, The Voyce of the Silence: "Eres Tú mismo el objeto de toda tu búsqueda, la Voz intacta que resuena a través de la eternidad, libre de todo cambio, del pecado, los siete sonidos en uno, la Voz del Silencio. Om tat Sat."
} 
Por último, aludía a la necesaria seriedad que la actividad filosófica había de tener para Wittgenstein. ${ }^{85}$ Lo que ahora podríamos añadir es que, para James, la seriedad, y la solemnidad, de la que el estilo wittgensteiniano no está desde luego huérfano, eran características de la experiencia religiosa. ${ }^{86}$

En determinado momento de su obra, James dice, hablando de la pureza de vida, que la persona santa es extremadamente sensible a la discordancia interna, "haciéndosele intolerable cualquier inconsistencia o confusión". ${ }^{87}$ Bien podría decirse que la filosofía de Wittgenstein fue insobornable, obsesivamente pura.

\section{BIBLIOGRAFÍA}

Ariso, J.M.,"Ich bin wahnisinnig geworden. Me he vuelto loco", en M. Rodríguez (comp.), La mente en sus máscaras, Biblioteca Nueva, Madrid, 2005, pp. 269-290.

Baum, Wilhelm, Ludwig Wittgenstein. Vida y obra, trad. Jordi Ibáñez, Alianza, Madrid, 1988.

Bouveresse, Jacques, Wittgenstein. La modernidad, el progreso y la decadencia, trad. Juan C. González y Margarita M. Valdés, Instituto de Investigaciones Filosóficas-UnAM, México, 2006.

Drury, M.O'C., "Conversaciones con Wittgenstein", en R. Rhees, Recuerdos de Wittgenstein, trad. Rafael Vargas, Fondo de Cultura Económica, México, 1989, pp. 169-270.

Gellner, Ernest, Lenguaje y soledad, trad. Carmen Ors, Síntesis, Madrid, 2002.

Goethe, Johann Wolfgang, Fausto, trad. José María Valverde, Planeta, Barcelona, 1980.

Hume, David, "Sobre la superstición y el entusiasmo", en Ensayos políticos, trad. César Armando Gómez, Madrid, Unión Editorial, 1975, pp. 81-86.

—_, Investigación sobre los principios de la moral, trad. Gerardo López Sastre, Espasa-Calpe, Madrid, 1991.

${ }^{85}$ De nuevo se situaría aquí Wittgenstein en una órbita platónica, ya que para el filósofo ateniense la seriedad era una condición indispensable del carácter filosófico; cfr. su Carta VII. Hacia el final de su vida todavía le comentaba a Bouwsma: "Sólo alguien que piense podrá extraer algo de provecho a partir de lo que digo. Citó la excepción de unos pocos de sus alumnos, que poseían cierto grado de obsesión y que eran serios" (L. Wittgenstein y O. Bouwsma, Últimas conversaciones, p. 28).

86 “Para los hombres corrientes 'religión', tenga los especiales significados que tenga, siempre significa un estado de ánimo serio" (Las variedades de la experiencia religiosa, p. 69).

${ }^{87}$ Ibid., p. 391.

Diánoia, vol. LII, no. 59 (noviembre 2007). 
James, William, Pragmatismo. Un nuevo nombre para antiguos modos de pensar, trad. Luis Rodríguez Aranda, Orbis, Barcelona, 1984.

- The Letters of William James, ed. Henry James, Atlantic Monthly Press, Boston, 1920, 2 vols.

—_ Las variedades de la experiencia religiosa, trad. José Francisco Yvars, Península, Barcelona, 2002.

López Sastre, Gerardo, "Un diálogo imaginario sobre el mundo religioso. William James y David Hume se encuentran", en J. De Salas y F. Martín (comps.), Aproximaciones a la obra de William James, Biblioteca Nueva, Madrid, 2005, pp. 137-156.

Malcolm, Norman, Wittgenstein: A Religious Point of View?, Routledge, Cornwall, 1993.

Mc Guinness, Brian, Wittgenstein. El joven Ludwig (1889-1921), trad. Huberto Marraud González, Alianza, Madrid, 1991.

Monk, Ray, Ludwig Wittgenstein. El deber de un genio, trad. Damián Alou, Anagrama, Barcelona, 1994.

Platón, Las cartas, trad. Margarita Toranzo, Instituto de Estudios Políticos, Madrid, 1970.

Sanfélix, V., "Una filosofía del espíritu. Wittgenstein y la cuestión judía", en M. Rodríguez (comp.), La mente en sus máscaras, Biblioteca Nueva, Madrid, 2005, pp. 291-305.

Taylor, Charles, Las variedades de la religión hoy, trad. Ramón Vilà Vernis, Paidós, Barcelona, 2003.

Von Wright, George Hendrik, Retrato del joven Wittgenstein, trad. Juan José Lara Peñaranda, Tecnos, Madrid, 2004.

Wittgenstein, Ludwig, Diarios secretos, trad. Andrés Sánchez Pascual e Isidoro Reguera, Alianza, Madrid, 1991.

— Cartas a Russell, Keynes y Moore, trad. Néstor Míguez, Taurus, Madrid, 1979.

—_, "Notas sobre lógica", en varios, Sobre el Tractatus logico-philosophicus, trad. J.L. Blasco y A. García Suárez, Teorema, Universidad de Valencia, Valencia, 1972, pp. 6-47.

—_ Diario filosófico (1914-1916), trad. Jacobo Muñoz e Isidoro Reguera, Ariel, Barcelona, 1982.

— - Tractatus logico-philosophicus, trad. Jacobo Muñoz e Isidoro Reguera, Alianza, Madrid, 1991.

_- Luz y sombra. Una vivencia(-sueño) y un fragmento epistolar, trad. Isidoro Reguera, Pre-textos, Valencia, 2006.

—_ Conferencia sobre ética, trad. Fina Birulés, Paidós, Barcelona, 1989.

- Movimientos del pensar. Diarios 1930-32/1936-37, trad. Isidoro Reguera, Pre-textos, Valencia, 2000.

—, Aforismos. Cultura y valor, trad. Elsa Cecilia Frost, Espasa Calpe, Madrid, 1995. 
Wittgenstein, Ludwig y Oets Kolk Bouwsma, Últimas conversaciones, trad. Miguel Ángel Quintana Paz, Sígueme, Salamanca, 2004.

Wuchterl, K. y A. Hübner, Ludwig Wittgenstein in Selbstzeugnissen und Bilddokumenten, Rowohl, Reinbeck, 1979.

Recibido el 25 de enero de 2007; aceptado el 28 de junio de 2007.

Diánoia, vol. LII, no. 59 (noviembre 2007). 